Nidhomul Haq Vol 3 No: 1 Maret 2018

ISSN 2503-1481

\title{
AHLU AL-SUNNAH WA AL-JAMAAH DALAM PERSPEKTIF SAID AQIL SIRADJ
}

\author{
Muhammad Endy Fadlullah \\ Dosen Institut Agama Islam Ibrahimy Banyuwangi \\ mefadlullah@gmail.com
}

\begin{abstract}
The discourse about Ahlu al-Sunnah wa al-Jamaah is still very interesting among academics. This term becomes an idol for every stream and is raised within the scope affirming its status as a surviving stream of the world and the hereafter (firqah al-Najiah). Ahlu al-Sunnah wa al-Jamaah became fertile because it is supported by the hadith of the Prophet who indeed came from 73 groups of Islam only one who survived the Ahlu alSunnah wa al-Jamaah group. Ahlu al-Sunnah wa al-Jamaah by Said Aqil as People who have a method of religious thinking that covers all aspects of life based on the foundations of moderation, maintaining balance and tolerance. Ahlu al-Sunnah wa al-Jamaah is a school that will become a Manhaj al-Fikr, as it is only an attempt to find a middle ground between the various streams. Ahlu al-Sunnah wa al-Jamaah there is no limitations and provisions that should be the same as Imam Abu Hasan al-Asy'ari or al-Maturidi but the pillars of Ahlu al-Sunnah wa al-Jamaah understand this must-have differences and opinions in interpreting the source of religion not become the gulf as long as still holding pillars (rukn) Ahlu al-Sunnah wa al-Jamaah namely the divinity (uluhiyah), apostles (Nubuwah) and the end (al-Ma'd).
\end{abstract}

Keywords: Ahlu al-Sunnah wa al-Jamaah, Said Aqil Siradj

\section{A. PENDAHULUAN}

Diskursus tentang Ahlu al-Sunnah wa alJamaah (Aswaja) masih sangat menarik diperbincangkan di kalangan akademisi. Istilah ini diperebutkan setiap aliran dan dimunculkan di permukaan dalam rangka meneguhkan statusnya sebagai aliran yang selamat dunia dan akhirat (firqah al-najiah). Perdebatan dan perebutan istilah Ahlu alSunnah wa al-Jamaah menjadi subur karena didukung oleh hadits Nabi yang menegaskan bahwa dari 73 golongan Islam hanya satu yang selamat yaitu golongan Ahlu al-Sunnah wa al-Jamaah. Term ini menjadi topik yang menarik karena (1) Aswaja menjadi sebuah identitas teologis yang diperebutkan oleh berbagai aliran maupun organisasi Islam, (2) substansi Ahlu al-Sunnah wa al-Jamaah masih menjadi pemahaman yang kontroversial di kalangan pemikir-pemikir muslim; dan (3) pemahaman Ahlu al-Sunnah wa al-Jamaah ternyata belum tuntas di kalangan umat Islam.
Geliat para pemikir muslim untuk merekonstruksi konsep Ahlu al-Sunnah wa alJamaah di era modern juga menggugah Ketua Umum Pengurus Besar Nandlatul Ulama (PBNU) periode 2015-2020 Said Aqil Siradj. Konsepsi Ahlu al Sunnah wa al-Jamaah yang diprakarsai oleh pendiri Nahdlatul Ulama (NU) Hasyim Asy'ari dan dipegang teguh selama ini direkonstruksi ulang. Konsep yang selama ini disakralkan oleh mayoritas warga Nahdliyin dianggap perlu dirubah dan disesuaikan dengan tuntutan zaman modern. Ahlu al-Sunnah wa al-Jamaah mestinya tidak dipahami secara tekstual dan terbatas namun harus dipahami secara kontekstual dan berkemajuan. Secara historis munculnya istilah ini disebabkan merebaknya sekte yang mengklaim bahwa mereka lebih baik dibanding sekte atau oraganisasi yang lain. Maka Ahlu al-Sunnah wa al-Jamaah muncul sebagai sebuah jawaban atas perpecahan yang terjadi di kalangan umat Islam di masa itu.

Sebagai sebuah solusi atas pertikaian dan perdebatan ini Ahlu al-Sunnah wa al-Jamaah mestinya muncul untuk memberikan ruang 
ISSN 2503-1481

seluas-luasnya bagi berbagai aliran dan pemahaman yang beragam untuk bersatu dalam bingkai Ahlu al-Sunnah wa al-Jamaah. Sebab secara historis munculnya Ahlu alSunnah wa al-Jamaah ditandai dengan tampilnya banyak tokoh yang bersikap moderat dan netral atas segala konflik teologis dan politis yang terjadi waktu itu. Hasan Basri, Fudhail Ibnu Iyadh, Ibnu Sirrin, Malik Ibnu Dinar, abdul Wahid Ibnu Zaid, Sufyan al tsauri lain-lainnya. Itulah cikal bakal dari madzhab Ahlu al-Sunnah wa alJamaah. Mereka bersikap netral dan tidak memihak salah satu partai yang ada dan mereka juga lebih moderat, berorientasi pada kegiatan ilmiah dan jauh dari kegiatan politik prakstis pada waktu itu.

\section{B. HASIL DAN PEMBAHASAN}

\section{Biografi Said Aqil Siradj}

Said Aqil Siradj lahir pada 3 Juli 1953 dari pasangan Aqil Siradj dan Afifah Harun. Said tumbuh dari keluarga religius berkultur pesantren. Ayahnya adalah seorang kyai yang cukup disegani, pengasuh pondok pesantren Tarbiyatul Mubtadiin di daerah Kempek Palimanan Cirebon Jawa Barat. Sejak kecil Said sudah dididik dengan sistem pendidikan pesantren, pendidikan selalu menjadi prioritas keluarganya. ${ }^{1}$

Pendidikan Said diawali di pesantren ayahnya sendiri dengan pola tradisional khas pesantren (salafiyah), dia juga berlajar secara formal di Sekolah Rakyat (SR). Said kemudian melanjutkan studi ke pondok pesantren Hidayatul Mubtadiin Lirboyo Kediri asuhan KH. Mahrus Ali, mulai dari Madrasah Tasanawiyah (MTs) hingga menyelesaikan tingkat menegah atas (SLTA) pada rentang tahun 1965-1970. Said kemudian melanjutkan pendidikannya di Pesantren al-Munawwir Krapyak Jogjakarta asuhan KH. Ali Ma'sum di pondok pesantren Krapyak tahun 1972-1975. Setelah menimba ilmu di Jogjakarta Said menempuh pendidikan di Universitas King Abdul Aziz cabang Makkah bidang pendidikan usuluddin dan dakwah, setelah lulus pada tahun 1982, Said melanjutkan ke jenjang magister (lulus 1987) dan doktoral (lulus 1994) di Universitas

\footnotetext{
1 Mohammad Dawam Sukardi, NU Sejak Lahir (Dari Pesantren Untuk Bangsa; Kado Buat Kyai Said), (Jakarta: SAS Center, 2010), 12.
}

Ummu al-Qura jurusan Perbandingan Agama. $^{2}$

Intelektualitas Said terlihat saat puncak studi doktoralnya, disertasinya yang berjudul Shillatu Bi Al Kalam Fi Al Tasawuf Al Falsafi (Relasi Tuhan Dengan Alam Kosmos: Perspektif Tasawuf Falsafi) sempat menjadi kontroversi di kalangan intelektual Ummu alQura yang notabene mengharamkan diskursus tasawuf falsafi, meski demikian Said mampu mempertahankan disertasinya yang dilengkapi dengan seribu lebih literatur ilmiah dengan predikat cumlaude.

Setelah menyelesaikan studi doktoralnya Said kembali ke Indonesia dan langsung diangkat menjadi wakil Katib Am Syuriah di PBNU, salah satu Ormas Islam terbesar di Indonesia. Selama dalam kepengurusan, Said kerap memunculkan pendapat dan wacanawacana kontroversial. Pernyataanpernyataannya dalam wacana teologi, madzhab, dan tasawuf cenderung dianggap berani dan keluar dari pakem ortodoksi bagi kalangan Nahdliyin yang mayoritas bercorak konservatif. Orasinya seputar latar belakang lahirnya ahlus sunnah wal jamaah mendapat kritikan tajam dari berbagai pihak, sampai muncul pengkafiran dirinya dari 12 kiyai NU kala itu. Akan tetapi saat diadakan forum tabayyun oleh para kiyai-kiyai NU, justru disitulah tampak kecerdasan dan keluasan referensi keilmuan Said dalam memahami Islam. Sehingga Pengurus Besar Nahdlatul Ulama (PBNU) merasa perlu menggelar halaqah khusus untuk merekonstruksi pemahaman ahlus sunnah wal jamaah, suatu doktrin yang selama ini cenderung disakralkan. ${ }^{3}$

Epistimologi Ahlu al-Sunnah wa alJamaah

Sebelum Rasulullah SAW meninggal dunia, beliau pernah bersabda bahwa umat Islam akan berpecah-belah sebanyak 73 golongan, di antara sekian banyak itu hanya satu golongan yang dianggap benar dan dijamin bebas dari siksa api neraka, yaitu golongan yang disebut Ahlu al-Sunnah wa alJamaah. Sedang lainnya akan dimasukkan ke dalam api neraka sebagaimana hadis berikut:

\footnotetext{
2 Said Aqil Sirad, Islam Kebangsaan Fiqh Demokratik Kaum Santri, (Jakarta: Pustaka Ciganjur, 1999), iv.

${ }^{3}$ Said Aqil Siradj, Islam Kebangsaan Fiqh...., iv.
} 
Nidhomul Haq Vol 3 No: 1 Maret 2018 ISSN 2503-1481

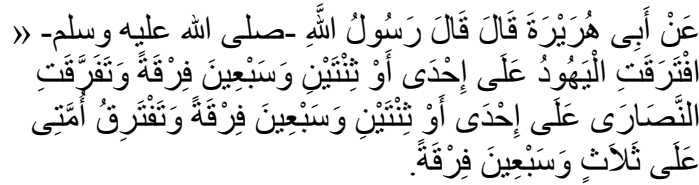

Dari Abu Hurairah RA, Rasulullah SAW bersabda; kaum Yahudi telah terpecah menjadi tujuh puluh satu (71) golongan atau tujuh puluh dua (72) golongan, dan kaum Nasrani telah terpecah menjadi tujuh puluh satu (71) atau tujuh puluh dua (72) golongan, dan ummatku akan terpecah menjadi tujuh puluh tiga (73) golongan (HR. Abu Dawud).

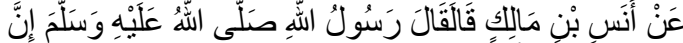

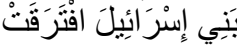

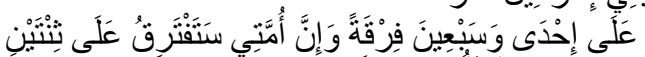

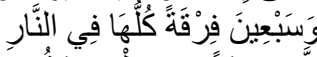

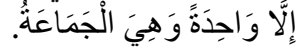

Dari Anas bin Malik RA berkata: Rasulullah SAW bersabda; sesungguhnya bani Israil telah berpecah belah menjadi 71 golongan dan umatku akan berpecah belah menjadi 72 golongan. Semuanya akan akan masuk neraka kecuali satu golongan saja yang selamat, yaitu golongan al-Jamaah (HR. Ibnu Majah).

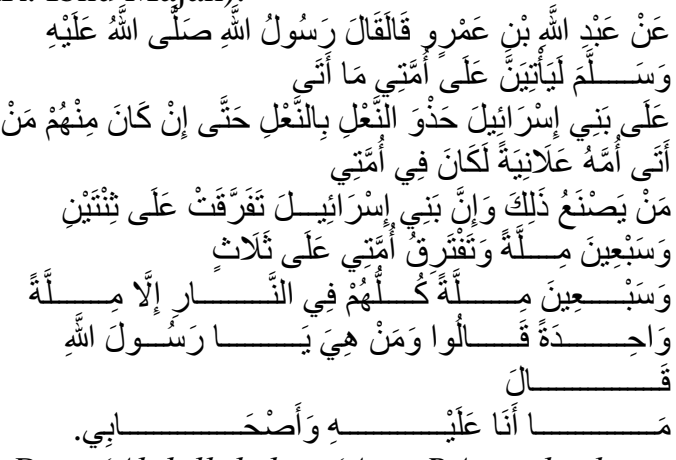

Dari 'Abdullah bin 'Amr RA, ia berkata; Rasulullah SAW bersabda; Sungguh akan terjadi pada ummatku, apa yang telah terjadi pada ummat bani Israil sedikit demi sedikit, sehingga jika ada di antara mereka (Bani Israil) yang menyetubuhi ibunya secara terang-terangan, maka niscaya akan ada pada ummatku yang mengerjakan itu. Dan sesungguhnya bani Israil berpecah menjadi tujuh puluh dua millah, semuanya di Neraka kecuali satu millah saja dan ummatku akan terpecah menjadi tujuh puluh tiga millah, yang semuanya di Neraka kecuali satu millah. (para Shahabat) bertanya, 'Siapa mereka wahai Rasulullah? Beliau Shallallahu alaihi wa sallam menjawab, Apa yang aku dan para Shahabatku berada di atasnya" (HR. Ibnu Majah).
Perpecahan yang terjadi di kalangan umat Islam yang diterangkan di hadits ini menurut Syaikh al-Bagdadi dalam kitabnya al farqu baina al firaq, sebagaimana dikutip Nur Sayyid Santoso, sebenarnya tidak menunjukkan arti bilangan sesungguhnya tetapi betapa banyaknya perpecahan itu terjadi, sehingga menimbulkan golongangolongan yang sulit dihitung satu persatu. Kemudian satu dari 73 golongan tersebut ialah golongan yang selamat dari siksaan api neraka yakni yang disebut ahlu al-Sunnah wa al-jamaah ${ }^{4}$. Pemahaman Jumlah satu golongan yang selamat ini juga masih menjadi perdebatan, sebagian memahami siapapun akan selamat selama memegang teguh Ahlu al-Sunnah wa al-Jamaah, yakni kelompok yang mengikuti apa yang diajarkan Nabi dan sahabatnya sebagaimana dijelaskan dalam hadis di atas.

Ahlu al-Sunnah wal al-Jamaah berasal dari tiga kata yakni ahlu, sunnah, dan jamaah. Secara bahasa Ahlun artinya keluarga, famili atau kerabat. ${ }^{5}$ Menurut Fairuzabadi ahlu dapat berarti pemeluk aliran atau pengikut mazhab jika dikaitkan dengan aliran atau madzhab. ${ }^{6}$ Sedangkan menurut Ahmad Amin kata ahlu merupakan badal al nisbah sehingga jika kaitkan dengan al sunnah mengandung arti orang yang mempunyai paham Sunni. ${ }^{7}$

Sunnah secara bahasa berarti peri kehidupan dan perilaku. Sunnah juga mempunyi arti al-thariqah (jalan dan perilaku) baik jalan dan perilaku tersebut benar atau keliru9. Secara terminologis Hasyim Asy'ari mendefinisikan sunnah sebagai berikut:

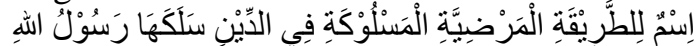

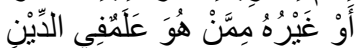

\footnotetext{
${ }^{4}$ Nur sayyid santoso, sejarah teologi islam dan akar pemikiran ahlus sunnah wal jamaah (Yoyakarta: Pustaka Pelajar, 2014), 82.

5 Ahmad Warson Munawir, Kamus al-Munawwir Indonesia-Arab Terlengkap (Surabaya: Pustaka Progresif, 2012), 46.

6 Al-Fairuzabadi, 1987, al-Qamus al-Muhith, (Beirut: Muassasah al-Risalah), 1245.

7 Ahmad Amin, Duhr al-Islam Juz Iv (Beirut: Darul Kitab Al Arabi, 1953), 96.

8 Ahmad Warson Munawir, Kamus al-Munawwir Indonesia......, 669.

${ }^{9}$ Idrus Ramli, Madzhab As'ari Benarkah Ahlus Sunnah Wal Jamaah? Jawaban Terhadap Aliran Salafi. (Surabaya: Khalista, 2009), 176.
} 
Nidhomul Haq Vol 3 No: 1 Maret 2018 ISSN 2503-1481

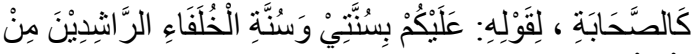

$$
\begin{aligned}
& \text { بَعْدِين }
\end{aligned}
$$

Sebuah jalan yang diridlai (Allah) yang ditempuh dalam agama, yaitu yang ditempuh oleh Rasulullah SAW dan yang lainnya, yang faham terhadap agama dari kalangan para sahabat, berdasarkan sabda Nabi ikutilah sunnahku dan sunnah khaulafaur rasyidin sesudahku. ${ }^{10}$

Kata terakhir jamaah mengandung arti sekelompok, kumpulan dan sekawan. ${ }^{11} \mathrm{Al}$ Jama'ah adalah sekumpulan orang yang memiliki tujuan. Jika dikaitkan dengan madzhab mempunyai arti sekumpulan orang yang berpegang teguh pada salah satu imam madzhab dengan tujuan mendapatkan keselamatan dunia dan akhirat. ${ }^{12}$

Ahlu al-Sunnah wa al-Jamaah merupakan aliran kalam yang memiliki komitmen berpegang teguh pada hadits-hadits Nabi sebagai reaksi terhadap aliran Mu'tazilah yang kurang kuat berpegang teguh pada hadits Nabi, dan merupakan mayoritas kaum Muslimin ('Ammah al-Muslimin). Aliran ini dibangun Abu Hasan al-Asy'ari dan Abu Mansur al-Maturidi. Kedua tokoh ini, terutama al-Asy'ari banyak mewarnai aliran ini mulai isi (content) maupun doktrindoktrinnya. ${ }^{13}$

Istilah Ahlu al-Sunnah wa al-Jamaah sebagai sebuah aliran dalam Islam baru nampak pada periodesasi Ashab al-Asy'ari seperti al-Baqilani (w. 403 H.), al Baghdadi (w. 429 H.) dll. Meskipun demikian mereka secara tidak tegas membawa bendera Ahlu alSunnah wa al-Jamaah. ${ }^{14}$ Pernyataan tegas tentang istilah Ahlu al-Sunnah wa al-Jamaah baru dijumpai pada pendapat al-Zabidi (w. $1205 \mathrm{H}$.) dalam karya nya Ithafu al-Sadah alMuttaqin yang menjelaskan bahwa Ahlu al-

10 Hasyim Asyari, Risalah Ahlu Sunnah Wal Jamaah (Jakarta: LTN PBNU, 2011), 3.

11 Ahmad Wason Munawir, Kamus Al Munawwir....., 209.

12 Said Aqil Siradj, Ahlussunnah Wal Jama'ah; Sebuah Kritik Historis, (Jakarta: Pustaka Cendikia Muda, 2008), 5.

13 Mujamil Qomar, Implementasi Aswaja dalam Perspektif NU Di Tengah Kehidupan Masyarakat. Kontemplasi, Volume 02 Nomor 01, Agustus 2014., 165.

14 Said Aqil Siradj, Ahlussunnah Wal Jama'ah; Sebuah Kritik....., 19.
Sunnah wa al-Jamaah adalah para penganut al-Asy'ari dan al-Maturidi.

Said Aqil Siradj menilai bahwa term Ahlu al-Sunnah wa al-Jamaah di masa Ashabu alAsy'ari hanya klaim belaka karena diakui atau tidak definisi terminologis yang baku tentang Ahlu al-Sunnah wa al-Jamaah masih belum terformulasikan secara utuh dan holistik. Landasan tentang definisi Ahlu al-Sunnah wa al-Jamaah adalah hadits Nabi ma ana alaihi wa ashabi. Tentu ini bukan definisi karena cakupannya bisa ditarik oleh semua mazhab dan aliran Islam yang ada di dunia Islam. ${ }^{15}$

Oleh sebab itu Ahlu al-Sunnah wa alJamaah oleh Said Aqil didefinisikan sebagai orang-orang yang memiliki metode berfikir keagamaan yang mencakup semua aspek kehidupan yang berlandaskan atas dasar-dasar moderasi, menjaga keseimbangan dan toleransi. Ahlu al-Sunnah wa al-Jamaah bukanlah sebuah mazhab akan tetapi sebuah Manhaj al-Fikr, sebab ia hanya sebuah upaya mencari jalan tengah antara berbagai aliran yang ada. ${ }^{16}$

Sikap moderat Ahlu al-Sunnah wa alJamaah tercermin dari metode pengambilan hukum (Istinbath) yang tidak semata-mata menggunakan nash, namun juga memperhatikan posisi akal. Begitu pula dalam wacana berpikir yang konsisten menjembembatani antara wahyu dengan akal. Metode (manhaj) seperti ini yang yang diimplementasikan Imam Madzhab empat serta generasi berikutnya dalam menghasilkan hukum-hukum hukum. Sifat netral (tawazun) berkaitan dengan sikap mereka dalam politik. Ahlu al-Sunnah wa al-Jamaah tidak terlalu membenarkan aliran keras (ekstrim). Namun jika dihadapkan dengan penguasa yang lalim, mereka tidak segan-segan mengambil jarak dan mengadakan aliansi. Artinya Ahlu alSunnah wa al-Jamaah lebih fleksibel dan akomodatif meskipun masih dalam batas tawazun. Keseimbangan (ta'adul) Ahlu alSunnah wa al-Jamaah terefleksi pada kiprah mereka dalam kehidupan sosial, cara mereka bergaul serta kondisi sosial budaya mereka. Begitu pula sikap toleransi Ahlu al-Sunnah

15 Said Aqil Siradj, Ahlus Sunnah Wal Jamaah Dalam Lintas Sejarah (Yogyakarta: LKPSM, 1997), 20.

16 Mastuki Hs, Kiai Menggugat Mengadili Pemikiran Kang Said, (Jakarta: Fatma Press, 1999), 2. 
Nidhomul Haq Vol 3 No: 1 Maret 2018 ISSN 2503-1481

wa al-Jamaah tercermin dalam dalam kehidupan sosial dengan sesama muslim yang yang tidak mengkafirkan ahlu qiblat serta senantiasa bersikap toleransi pada sesama muslim dan umat manusia pada umumnya. ${ }^{17}$

Definisi ini memberikan ruang yang sangat luas bagi aliran-aliran lain untuk bisa berfusi dalam konsepsi Ahlu al-Sunnah wa alJamaah. Konsekuensi logisnya maka aliran Syiah (Imamiyah) dan Mutazilah bisa dikategorikan Ahlu al-Sunnah wa al-Jamaah. Kenapa demikian karena keduanya masih termasuk sekte agama Islam dan memiliki kesamaan dalam keyakinan kepada tuhan (Ilahiat), kenabian (nubuwat) dan hari kebangkitan $\left(m a^{\prime} d\right)$. Langkah Said Aqil ini bisa dimaknai sebagai upaya untuk mengakomodir aliran-aliran lain untuk bersatu dalam bingkai aliran-aliran Islam yang memiliki landasan ajaran tauhid, mengimani kenabian, keyakinan akan hari kebangkitan, serta bersikap moderat dan netral.

Sejarah Munculnya Ahlu Al Sunnah wa Al Jamaah

Istilah Ahlu al-Sunnah wa al-Jamaah tidak dikenal di zaman Nabi Muhammad SAW maupun di masa pemerintahan Al-Khulafa Al Rasyidin, bahkan tidak dikenal di zaman pemerintahan Bani Umayah (41-133 H /611750 M). Term Ahlu al-Sunnah wa al-Jamaah sebetulnya merupakan diksi baru, atau sekurang-kurangnya tidak pernah digunakan sebelumnya di masa Nabi dan pada periode Sahabat. ${ }^{18}$

Kemunculan Ahlu al-Sunnah wa alJamaah merupakan reaksi atas perpecahan yang terjadi di kalangan umat Islam. Setelah terjadinya arbritrase (tahkim) antara pendukung Ali ibnu Abi Thalib dengan Muawiyah Ibnu Abu Sufyan umat Islam tercerai berai dalam banyak firqah (faksi politik). Pada mulanya berupa gerakan politik murni kemudian dalam perkembangannya telah melewati batas-batas politik dan memasuki ranah teologis. ${ }^{19}$

Faksi-faksi itu yang awalnya berupa gerakan politik akhirnya menjadi gerakan

17 Said Aqil Siradj, Ahlus Sunnah Wal Jamaah Dalam Lintas......, 2.

18 Said Aqil Siradj, Ahlussunnah Wal Jama'ah; Sebuah Kritik....., 6.

19 Said Aqil Siradj, Ahlus Sunnah Wal Jamaah Dalam Lintas....., 44. ideologis. Kondisi internal politik umat Islam tersebut yang menjadi sebab suburnya perbedaan, terutama dalam masalah teologis. Pengaruh internal sperti Yahudi, Nashrani dan filsafat Yunani juga menjadi faktor pemicu semakin luasnya perbedaan dalam tubuh Islam. Faksi-afaksi itu di antaranya: Syiah, Khawarij, Jabariyah, Qadariyah dan Murjiah.

Di tengah maraknya pertikaian antar fraksi politik (firqah) yang dibungkus dengan sampul aqidah, muncullah pemikiran sebagian tabiin yang sejuk, moderat dan tidak terlalu ekstrim. Kelompok terakhir inilah yang tidak mau terseret terlampau jauh dalam aktifitas politik praktis. Mereka juga tidak mudah menuduh orang lain kafir. Aktifitasnya lebih bersifat kultural, ilmiah dan berusaha mencari jalan kebenaran secara jernih. Komunitas ini dipelopori oleh Hasan Basri serta para tabiin yang lain. Sikap Hasan Basri inilah sebenarnya yang direduksi sebagai pemikiran Ahlu al-Sunnah wa al-Jamaah. Sehingga, tidak benar jika Ahlu al-Sunnah wa al-Jamaah baru muncul pada masa Abu Hasan al-Asy'ari dan Abu Manshur al-Maturidi ${ }^{20}$. Dari sikap dan pemikiran Hasan Basri inilah kemudian diteruskan kepada muridnya kemudian sampailah kepada Abu Hasan alAsy'ari.

Ahlu al-Sunnah wa al-Jamaah muncul sebagai sebuah jawaban atas munculnya sekte dalam Islam yang melakukan deviasi dan monopoli dalam interpretasi sumber ajaran Islam. Munculnya Ahlu al-Sunnah wa alJamaah sebagai upaya dalam mencari jalan tengah atas konflik yang terjadi di masa itu. ${ }^{21}$ Ahlu al-Sunnah wa al-Jamaah di masa kini bisa dimaknai sebagai sebuah manhaj alfikr yang memadukan antara wahyu dan akal serta memberikan ruang bagi aliran-aliran yang muncul di akhir zaman.

Landasan Akidah Ahlu al-Sunnah wa alJamaah

Dasar keyakinan akidah ahlu al-Sunnah wa al-Jamaah harus dilandasi oleh dalil dan argumentasi yang definitif (qath' $i$ ) dari alQuran, hadits, ijmak dan argumentasi akal yang sehat. Berikut ini rincian dalil-dalil tersebut:

\footnotetext{
${ }^{20}$ Said Aqil Siradj, Ahlus Sunnah Wal Jamaah Dalam Lintas....., 65.

21 Mastuki Hs, Kiai Menggugat Mengadili Pemikiran....., 2.
} 
Nidhomul Haq Vol 3 No: 1 Maret 2018 ISSN 2503-1481

\section{1) Al-Quran}

Al-Quran adalah pokok dari semua argumentasi dan dalil. Al-Quran adalah dalil yang membuktikan kebenaran risalah Nabi Muhammad SAW. Al-Quran juga merupakan kitab terakhir yang menegaskan pesan-pesan kitab samawi sebelumnya ${ }^{22}$. Allah secara tegas memerintahkan umat muslim untuk mengembalikan persoalan yang diperselisihkan kepada Allah dan rasul-Nya:

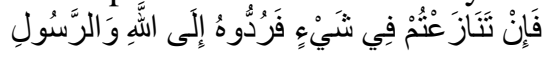

Kemudian jika kamu berlainan pendapat tentang sesuatu, maka kembalikanlah ia kepada Allah (al-Quran) dan rasul (al-hadits) (QS. Al-Nisa: 59).

Mengembalikan persoalan kepada Allah berarti mengembalikannya kepada al-Quran. Sedangkan mengembalikan persoalan kepada Rasul berati mengembalikannya kepada hadits Nabi yang sahih.

\section{2) Al Hadits}

Hadits adalah dasar kedua dalam penetapan akidah-akidah dalam Islam. Tetapi tidak semua hadits dapat dijadikan dasar dalam menetapkan akidah. Hadits yang dapat dijadikan dasar dalam menetapkan akidah adalah hadits yang perawinya masih dipercaya oleh ulama. Sehingga hadits yang perawinya masih diperselisihkan oleh ulama maka tidak dapat dijadikan dasar dalam menetapkan akidah. Hadits yag dapat dijadikan dasar dalam menetapkan akidah adalah hadits mutawatir, yaitu hadits yang mencapai peringkat tertinggi dalam kesahihan. Di bawah hadits mutawatir ada hadits masyhur sedangkan hadits yang peringkatnya di bawah hadits masyhur tidak dapat dijadikan dasar argumentasi dalam menetapkan sifat-sifat Allah.

3) Ijmak

Ijmak ulama yang mengikuti ajaran ahlu al-haq dapat dijadikan argumentasi dalam menetapkan akidah. Dalam hal ini seperti dasar yang melandasi penetapan bahwa sifatsifat Allah itu tidak ada permulaannya (Qadim) adalah ijmak ulama yang qath' $i$.

4) Akal

Dalam ayat-ayat al-Quran Allah SWT telah mendorong hamba-hamba-Nya agar merenungkan semua yang ada di alam raya,

\footnotetext{
22 Idrus Ramli, Madzhab As'ari Benarkah Ahlus Sunnah Wal Jamaah....., 184.
}

agar dapat mengantarkan kepada keyakinan tentang kekuasaan Allah. ${ }^{23}$

Pandangan Said Aqil Siradj tentang Ahlu al-Sunnah wa al-Jamaah

Ahlu al-Sunnah wa al-Jamaah dalam perspektif NU sebagaimana ditegaskan dalam Anggaran Dasarnya, bahwa Nahdlatul Ulama sebagai Jam'iyah Diniyah Islamiyah berakidah Islam menurut paham Ahlu alSunnah wa al-Jamaah dan mengikuti salah satu mazhab empat: Hanafi Maliki, Syafii dan Hanbali. $^{24}$ Pernyataan ini dijabarkan lebih rinci lagi dengan tambahan aspek tasawuf sebagai berikut: Pertama, dalam bidang akidah, Nahdlatul Ulama mengikuti paham Ahlu al-Sunnah wa al-Jamaah yang dipelopori oleh Imam Abu Hasan al-Asy'ari dan Imam Abu Mansur al-Maturidi; Kedua, dalam bidang fiqih, Nahdlatul Ulama mengikuti jalan pendekatan (al-madhhab) salah satu dari mazhab Abu Hanifah alNu'man, Imam Malik Ibn Anas, Imam Muhammad Ibn Idris al-Syafii, dan Ahmad Ibn Hanbal. Ketiga, dalam bidang tasawuf mengikuti antara lain Imam al-Junaid alBaghdadi, Imam al-Ghazali serta imam-imam yang lain. ${ }^{25}$

\section{Bidang Akidah}

Diskursus akidah dalam paham Ahlu alSunnah wa al-Jamaah sudah berlangsung sejak lama bahkan jauh sebelum Abu Hasan al-Asy'ari (w. 324 H.) maupun Abu Mansur al-Maturidi (w.332 H.), sehingga tidak terlalu salah seandainya pemikiran akidah Ahlu alSunnah wa al-Jamaah tidak persis sebagaimana pendapat-pendapat al-Asy'ari dan al-Maturidi. ${ }^{26}$

Abdul Qahir al-Baghdadi al-Isfirany secara tegas menjelaskan bahwa semua umat Islam yang menyepakati (Ijmak) terhadap kebaruan (huduts) alam, mentauhidkan pencipta alam, mempercayai kenabian Muhammad SAW beserta risalah yang diembannya, meyakini al-Quran sebagai sumber hukum (Manba' al-Ahkam al-

\footnotetext{
${ }^{23}$ Idrus Ramli, Madzhab As'ari Benarkah....., 188.

${ }^{24}$ Anggaran Dasar......, 7.

25 Tim Perumus Konsep Sosialisasi Khittah Nahdlatul Ulama PWNU Jawa Timur, Wawasan Dasar Nahdlatul Ulama, (Surabaya: Tim Perumus Konsep Sosialisasi Khittah Nahdlatul Ulama PWNU Jawa Timur, 1994), 16-17

26 Said Aqil Siradj, Ahlus Sunnah Wal Jamaah Dalam Lintas....., 65.
} 
Nidhomul Haq Vol 3 No: 1 Maret 2018 ISSN 2503-1481

Syariah) serta Ka'bah sebagai kiblat shalatnya, mereka semua tergolong Ahlu alSunnah wa al-Jamaah. ${ }^{27}$

Cakupan Ahlu al-Sunnah wa al-Jamaah sangat luas dan tidak bisa dibatasi hanya pendapat al-Asy'ari karena sebelumnya telah banyak pemikiran yang masuk dalam cakupan Ahlu al-Sunnah wa al-Jamaah misalnya, pemikiran yang dikembangkan oleh Harits Ibnu Asad al-Muhasisbi (w. 241 H.), Ibnu Kullab (w. 204 H.), Imam Syafii (w. 204 H.), Imam Malik Ibnu Anas (w.191 H.) Imam Abu Hanifah (w. 150 H.) para tabiit tabiin, para tabiin, para sahabat bahkan sejak zaman Rasulullah SAW. ${ }^{28}$

Oleh sebab itu dalam Ahlu al-Sunnah wa al-Jamaah tidak ada batasan dan ketentuan harus persis seperti Imam Abu Hasan alAsy'ari ataupun al-Maturidi namun pilar-pilar paham Ahlu al-Sunnah wa al-Jamaah ini yang harus dipertahankan dengan demikian perbedaan pendapat dan pandangan dalam menginterpretasikan sumber agama tidak menjadi jurang pemisah selama masih memegang pilar-pilar (rukun) Ahlu al-Sunnah wa al-Jamaah.

Pilar pertama adalah ketuhanan (uluhiyah) mengupas tentang eksistensi Allah SWT di alam semesta. Selama orang masih memiliki jiwa tauhid yang murni kepada Allah dengan membuang semua bentuk kemusyrikan dan berpegang teguh kepada nash al-Quran dan al-Sunnah, maka orang tersebut masih tergolong Ahlu al-Sunnah wa al-Jamaah. Sikap ini berangkat dari prinsip dasar bahwa Ahlu al-Sunnah wa al-Jamaah selalu mencari jalan tengah (tawasuth), moderat dan tawazun. ${ }^{29}$

Pilar kedua adalah kenabian (Nubuwah) menjelaskan bahwa Allah SWT telah menurunkan wahyu kepada para Nabi dan Rasul sebagai utusan. Wahyu tersebut merupakan acuan jalan hidup umat manusia yang dapat menyelamatkan kehidupan mereka di dunia maupun di akhirat, menuju kabahagiaan lahir dan batin yang hakiki dan abadi.

${ }^{27}$ Abdul Qahir, Ibnu Muhammad al-Baghdadi alIsfirany al-Tamimi, al-Farqu Baina Alfiraq (Beirut: Dar al-Marifat, Tt), 13.

${ }^{28}$ Said Aqil Siradj, Ahlus Sunnah Wal Jamaah Dalam Lintas....., 65.

${ }^{29}$ Said Aqil Siradj, Ahlussunnah wal Jama'ah dalam Lintas......, 72.
Pilar ketiga adalah al-Ma'd yaitu keyakinan bahwa Allah akan membangkitkan manusia dari kubur, lalu memasuki hari kiamat. Pada hari itu, semua manusia akan menerima pembalasan atas semua amal perbuatannya (Yaum al-Jaza).Mereka yang perhitungan (Hisab) amalnya baik akan masuk surga sedangkan yang buruk akan masuk neraka. ${ }^{30}$

Tiga pilar inilah yang menjadi ukuran dalam menentukan orang, golongan atau partai dikategorikan sebagai Ahlu al-Sunnah wa al-Jamaah apa tidak, jika masih ada tiga rukun ini dalam keyakinannya maka siapapun bisa dikategorikan sebagai Ahlu al-Sunnah wa al-Jamaah.

\section{Bidang Sosial Politik}

Ahlu al-Sunnah wa al-Jamaah tidak memiliki patokan yang baku tentang bentuk negara. Negara diberikan kebebasan menentukan bentuk pemerintahannya, bisa demokrasi, kerajaan, teokrasi ataupun bentuk lainnya. Ahlu al-Sunnah wa al-Jamaah hanya memberikan kriteria (syarat-syarat) yang harus dipenuhi oleh suatu negara. Persyaratan yang harus dipenuhi oleh suatu negara tersebut adalah:

a. Prinsip Syura (musyawarah)

Prinsip ini didasarkan pada firman Allah QS. 42: 36-39. Menurut ayat di atas, syura atau musyawarah merupakan ajaran yang setara dengan iman kepada Allah, tawakkal, menghindari dosa besar, memberi maaf setelah marah, memenuhi titah ilahi, mendirikan shalat, memberikan shadaqah dan lain sebagainya. Sekan-akan musyawarah merupakan suatu bagian integral dari hakikat iman dan Islam.

\section{b. Prinsip al-Adl (keadilan)}

Menegakkan keadilan merupakan suatu keharusan dalam Islam terutama bagi para penguasa dan para pemimpin pemerintahan terhadap rakyat dan umat yang dipimpin. Dan ini didasarkan pada QS. 4: 58.

c. Prinsip al-Hurriyah (kebebasan)

Kebebasan dimaksudkan sebagai suatu jaminan bagi rakyat agar dapat melaksanakan hak-ha mereka. Hak-hak tersebut dalam syariat dikemas dalam al-Ushul al-Khams (lima prinsip pokok) yang menjadi kebutuhan primer bagi setiap insan. Kelima prinsip

\footnotetext{
30 Said Aqil Siradj, Ahlus Sunnah Wal Jamaah Dalam Lintas....., 73.
} 
Nidhomul Haq Vol 3 No: 1 Maret 2018

ISSN 2503-1481

tersebut adalah: a) hifdzu al-nafs (menjaga kehidupan) b) hifdzu al-din (menjaga agama) c) hifdzu al-mal (menjaga harta benda) d) hifdu al-nasl (menjaga keturunan) e) hifdzu al-irdh (menjaga kehormatan).

d. Prinsip al-Musawah (kesetaraan derajat)

Semua warga negara haruslah mendapatkan perlakuan yang sama. Semua warga negara memiliki kewajiban dan hak yang sama pula. Sistem kasta atau pemihakan terhadap golongan, ras, jenis kelamin atau pemeluk agama tertentu tidaklah dibenarkan.

\section{Bidang Istinbath al-Hukm (penggalian hukum)}

Dalam deretan sekte-sekte Islam (alMadzahib al-Islamiyah) terutama dalam lingkup fiqih (Syariah) tidak ditemukan kontroversi yang disebakan oleh polemik mutakallimin. Tetapi yang terjadi justru sebaliknya. Para mutakallimin, baik dari Mu'tazilah, Asy'ariyah, Maturudiyah maupun Salafiyin tersebar dalam berbagai madzhab fiqih. Hanya Syi'ah sebagi suatu madzab dalam telogis yang sekaligus memiliki madzhab fiqih tersendiri yang berasal dari para Imam mereka bahkan secara tegas Syi'ah mengikuti Imam Jafar al-Shadiq dalam bidang fiqih. ${ }^{31}$

Pemahaman Ahlu al-Sunnah wa al-Jamaah sebagai metode fikir (Manhaj al-Fikr) bukan mazhab harus menjadi titik awal kerangka berfikir dalam menggali hukum. Metode tersebut bersifat tawasuth, tawazaun, tasamuh dan selalu mencari jalan tengah (moderat) yang diterima oleh sebagian besar golongan (Sawad al-A'dzam). Jika berpegang pada paradigma ini, maka keberagaman mazhab dalam fiqih akan mudah terwadai.

Sebenarnya, tidaklah ditemukan pendapat (qaul) ulama yang secra tegas menutup otoritas ijtihad. Pintu ijtihad tertutup dengan sendirinya setelah muncul persyaratan bagi seorang mujtahid yaitu harus memiliki kapabilitas keilmuan yang sempurna. Perkembangan selanjutnya pemikiran kajian hukum Islam dikembangkan para ulama madzhab hal ini bukan berarti semangat kajian generasi ini mundur namun mereka tetap reflektif, krits, analitis, argumentatif dan sistematis. Implementasi pemikiran mereka terefleksikan pada karyanya yaitu kitab-kitab

\footnotetext{
${ }^{31}$ Said Aqil Siradj, Ahlus Sunnah Wal Jamaah Dalam Lintas....., 80.
}

dengan sistem syarah (penjelasan), khasiyah (catatan kaki). Kemudian muncul pula tahqiq (penelitian), dan ta'liq (komentar).

Dari keterangan di atas, sangtlah efektif keputusan Munas Nahdlatul Ulama di Lampung 1992 tentang bermadzhab secara qauli, jika masih memungkinkan penetapan masalah-maslah aktual. Kemudian, jika tidak dimungkinkan mengambil langkah dengan bermadzhab secara manhaji, maka metode istinbath jama'i (kolektif) merupakan terobosan yang brilian bagi kelangsungan sistem istinbath hukum dalam lingkungan Ahlu al-Sunnah wa al-Jamaah.

\section{Bidang Tasawuf}

Tasawuf dibagi menjadi dua yaitu tasawuf sunni (amali) dan tasawuf falsafi. Tasawuf sunni adalah tasawuf yang memilki karakter dinamis karena selalu mendahulukan syari'at. Seseorang tidak akan mecapai hakikat bila tidak melalui syari'at sedangkan proses pencapaian hakikat harus melalui maqomat (terminal-terminal).

Tasawuf falsafi adalah tasawuf yang konteksnya sudah memamsuki wilayah ontologi yakni berhubungan dengan Allah SWT dengan alam semesta (kosmologi) sehingga jika jenis tasawuf ini bebicara emanasi, inkarnasi, persatuan ruh Tuhan dan ruh manusia, keesaan dan seterusnya. Seorang sufi sebenarnya sangat memberikan motivasi untuk selalu dinamis. Kehidupan tasawuf merupakan suatu revolusi rohani, sehingga jika seseorang benar-benar berjalan pada kehidupan tasawuf yang lurus maka profesi dan karirnya tidak akan terlambat. Namun, sangat disayangkan tipologi para tokoh sufi tersebut saat ini semakin memudar. Hal ini disebabkan karena pemahaman tasawuf semenjak abad ke 5/6 $\mathrm{H}$. sudah mulai bergeser ke arah ritual. Titik tekan tasawuf hanya pada aspek-aspek formal, seperti wirid dzahir sebanyak-banyaknya, pemakaian simbol-simbol sufi dengan hudurnya hati.

\section{Analisis Konsep Ahlu al-Sunnah wa al-} Jamaah Said Aqil Siradj

Said Aqil Siradj memberikan batasanbatasan dalam mengkategorikan aliran-aliran atau seseorang masuk dalam kategori Ahlu alSunnah wa al-Jamaah atau tidak. Konsep yang ditawarkan oleh Said Aqil Siradj bahwa Ahlu al-Sunnah wa al-Jamaah bukanlah madzhab tapi sebuah Manhaj al-Fikr tentu menimbulkan polemik di tubuh internal NU 
ISSN 2503-1481

maupun di luar NU. Karena konsep ini menggugat konsep al-Sunnah wa al-Jamaah yang telah disakralkan oleh mayoritas warga NU. Hasyim Asy'ari selaku pendiri menegaskan bahwa dalam aspek keyakinan (akidah) Ahlu al-Sunnah wa al-Jamaah mengikuti paham yang dikembangakan oleh al-Asy'ari dan al-Maturidi. Konsepsi Ahlu alSunnah wa al-Jamaah Hasyim Asy'ari mengatakan jika keluar dari pemahaman alAsy'ari dan al-Maturidi maka sudah keluar dari Ahlu al-Sunnah wa al-Jamaah. Hal ini ditegaskan oleh Imam Murtadho al-Zabidi di dalam kitabnya Ithafu Saadah al-Muttaqin bahwa sejak zaman dulu kelompok yang disebut Ahlu al-Sunnah wa al-Jamaah adalah pengikut al-Asy'ari dan al-Maturidi.

Menurut hemat kami konsep ini memiliki sisi negatif yang membuka ruang bagi aliran lain untuk mengkaim dirinya sebagai Ahlu alSunnah wa al-Jamaah. Batasan bahwa Ahlu al-Sunnah wa al-Jamaah disematkan kepada aliran dalam koridor masih meyakini bahwa ketuhanan, kenabian dan hari akhir menimbulkan polemik baru. Pertama, Syi'ah Imamiyah sebagai sebuah aliran memiliki kesamaan dalam hal ini. Lima dasar (Ushul Khamsah) Syi'ah Imamiyah atau biasa disebut rukun iman Syi'ah berisi: ketuhanan (tauhid), kenabian (nubuwat), kepemimpinan (imamah), keadilan (al-adlu) dan hari akhir (al-ma'd). Dengan demikian Said Aqil berpendapat bahwa Syiah Imamiyah masih dalam kategori Ahlu al-Sunnah wa al-Jamaah. Tentu ini menimbulkan polemik baru di kalangan nahdliyin atau di luar mereka. Sebab, Ahlu al-Sunnah wa al-Jamaah dengan Syi'ah selama ini dipahami sebagai dua kutub yang berbeda. Satu sama lain tidak pernah menyatakan bisa disematkan istilah Ahlu alSunnah wa al-Jamaah. Bahkan selama ini dikonotasikan bahwa definisi negatif Syi'ah adalah Ahlus al-Sunnah dan sebaliknya definisi negatifnya Ahlu al-Sunnh adalah Syi'ah.

Kedua, Mu'tazilah sebagai aliran yang sempat menjadi sorotan dalam sejarah Islam berkat pencapaiannya dalam pembangunan peradaban Islam dibidang ilmu pengetahuan juga dikategorikan sebagai Ahlu al-Sunnah wa al-Jamaah. Kontribusi yang besar di bidang ilmu pengetahuan inilah mungkin yang menjadikan Said Aqil memasukkan Mu'tazilah sebagai golongan Ahlu al-Sunnah wa al-Jamaah. Sejarah mencatat berkat kebebasan berfikir dan keterbukaan terhadap ilmu pengetahuan inilah umat Islam berada di puncak tertinggi peradaban Islam (golden age) di masa lalu. Namun secara akidah Mu'tazilah dianggap masih masuk dalam bingkai Ahlu al-Sunnah wa al-Jamaah karena memiliki dasar yang sama di lima dasar (Ushul Khamsah): ketuhanan (tauhid), kenabian (nubuwat), tempat di antara dua tempat (manzilatun baina manzilataini), keadilan (al-Adlu) dan hari akhir (al-ma'd) sama halnya Syi'ah. Menelisik lebih jauh, Pemahaman ahlus sunnah yang luas ini sedikit banyak mengadopsi konsep Ahlu alSunnah wa al-Jamaah Abdul Qahir alBaghdadi al-Isfirany yang secara tegas menjelaskan bahwa semua umat Islam yang menyepakati (Ijmak) terhadap kebaruan (Huduts) alam, mentauhidkan pencipta alam, mempercayai kenabian Muhammad SAW beserta risalah yang diembannya, meyakini al-Quran sebagai sumber hukum (Manba' alAhkam al-Syariah) serta Ka'bah sebagai kiblat shalatnya, mereka semua tergolong Ahlu al-Sunnah wa al-Jamaah. ${ }^{32}$

Ketiga, dari segi metodologi konsep ini tidak konsisten dan cenderung dipaksakan. Terhadap dua aliran tadi (Mutazilah dan Syi'ah Imamiyah) ia tegas memasukkan keduanya dalam manhaj Ahlu al-Sunnah wa al-Jamaah namun menolak secara tegas salafi bagian dari Ahlu al-Sunnah wa al-Jamaah. Said aqil secara tegas menolak paham SalafiWahabi yang menurutnya tidak sesuai dengan nilai-nilai Ahlu al-Sunnah wa al-Jamaah yang mengedepankan sikap moderat dan selalu berada di tengah. Salafi lebih tepat dikategorikan sebagai neo Khawarij yang paham dan perilakunya sangat keras serta jauh dari ajaran Islam yang dibawa oleh Nabi Muhammad SAW. Jika perilaku keras Salafi terhadap kelompok lain seperti melempar tuduhan sesat, bid'ah dan khurafat dikategorikan bukan Ahlu al-Sunnah wa alJamaahbagaimana jika dibandingkan dengan Mu'tazilah yang memaksakan kehendaknya menjadi madzhab wajib negara? Bukankah Mu'tazilah juga melakukan tindak kekerasan dan intimidasi kepada umat Islam dalam tragedi mihnah Al Quran? Imam Ahmad Ibnu

\footnotetext{
32 Abdul Qahir, Ibnu Muhammad al-Baghdadi alIsfirany al-Tamimi, al-Farqu Baina......, 13.
} 
Nidhomul Haq Vol 3 No: 1 Maret 2018 ISSN 2503-1481

Hanbal salah seorang Imam madzhab fiqih menjadi saksi kekejaman khalifah al-Watsiq, al-Mutashim dan al-Watsiq yang berpaham Mu'tazilah. Karena jika mengacu pada aspek teologis aliran Salafi masih bisa dikategorikan Ahlu al-Sunnah wa al-Jamaah yang berlandaskan pada tiga pilar yakni ilahiyat, nubuwat dan ma'd.

Keempat, istilah Ahlu al-Sunnah wa alJamaah sebenarnya sudah dimunculkan sejak masa akhir sahabat (Sigharu al-Sahabah) ini anti tesis dari konsep Said Aqil yang menjelaskan istilah ini tidak muncul sampai akhir masa daulah Bani Umayyah. Sahabat Ibnu Abbas ketika melakukan tafsiran terhadap surat Ali Imran: 106 menjelaskan bahwa orang-orang yang wajahnya esok di hari kiamat putih bersih merekalah golongan Ahlu al-Sunnah wa al-Jamaah dan orangorang yang berilmu. Sedangkan orang-orang yang wajahnya hitam merekalah golongan ahlu bid'ah wa al-Dhalalah ${ }^{33}$. Hal ini menagaskan bahwa walaupun sebagai sebuah mahzab dan manhaj Ahlu al-Sunnah wa alJamaah belum terumuskan secara definitif namun sebagai sebuah nama dan istilah term ini sudah muncul di generasi akhir sahabat sebelum munculnya generasi tabiin dan tabiit tabiit tabiin seperti Hasan Basri dll.

Langkah dan upaya Said Aqil Siradj dalam merekonstruksi konsep Ahlu al-Sunnah wa alJamaah perlu diacungi jempol mengingat semangat dari upaya ini adalah dalam rangka merumuskan kembali Ahlu al-Sunnah wa alJamaah yang kontekstual, mampu mengakomodir seluruh sekte, aliran dan organisasi dalam bingkai Ahlu al-Sunnah wa al-Jamaah yang berlandasakan pada pilarpilar (rukun) Ahlu al-Sunnah wa al-Jamaah yaitu ketuhanan (Uluhiyah), Kenabian (Nubuwah) dan hari akhir (Al Ma'd).

\section{KESIMPULAN}

Ahlu al-Sunnah wa al-Jamaah oleh Said Aqil Siradj didefinisikan sebagai orang-orang yang memiliki metode berfikir keagamaan yang mencakup semua aspek kehidupan yang berlandaskan atas dasar-dasar moderasi, menjaga keseimbangan dan toleransi. Ahlu al-Sunnah wa al-Jamaah bukanlah sebuah mazhab akan tetapi sebuah Manhaj al-Fikr, sebab ia hanya sebuah upaya mencari jalan tengah antara berbagai aliran yang ada.

Ahlu al-Sunnah wa al-Jamaah tidak ada batasan dan ketentuan harus persis seperti Imam Abu Hasan al-Asy'ari ataupun al-Maturidi namun pilar-pilar paham Ahlu al-Sunnah wa al-Jamaah ini yang harus dipertahankan dengan demikian perbedaan pendapat dan pandangan dalam menginterpretasikan sumber agama tidak menjadi jurang pemisah selama masih memegang pilarpilar (Rukun) Ahlu al-Sunnah wa alJamaah yaitu ketuhanan (Uluhiyah), Kenabian (Nubuwah) dan hari akhir (Al $M a ' d)$.

\footnotetext{
${ }^{33}$ Hibbatullah Ibnu Hasan Ibnu Manshur al-Lalkai Abu Qasim, Syarhu Ushulu I'tiqad Ahlu al-Sunnah wa al-Jamaah Juz 2 (Riyadh: Daru al-Thaibah, 1980), 92.
} 
Nidhomul Haq Vol 3 No: 1 Maret 2018

ISSN 2503-1481

\section{DAFTAR PUSTAKA}

Al-Fairuzabadi. 1987. Al-Qamus al-Muhith. Beirut: Muassasah al-Risalah Amin, Ahmad. 1953. Duhr al-Islam Juz Iv. Beirut: Darul Kitab al-Arabi Asyari, Hasyim. 2011. Risalah Ahlu Sunnah Wal Jamaah. Jakarta: LTM PBNU

Hibbatullah Ibnu Hasan Ibnu Manshur al-Lalkai Abu Qasim, Syarhu Ushulu I'tiqad Ahlu al-Sunnah wa al-Jamaah Juz 2 (Riyadh: Daru al-Thaibah, 1980).

Hs, Mastuki. 1999. Kiai Menggugat Mengadili Pemikiran Kang Said. Jakarta: Fatma Press.

Ibnu Muhammad al-Baghdadi al-Isfirany al-Tamimi, Abdul Qahir. tt. Al-Farqu Baina alfiraq. Beirut: Dar al-Marifat

Munawir, Ahmad Warson. 2012. Kamus al-Munawwir Indonesia-Arab Terlengkap Surabaya: Pustaka Progresif.

Qomar, Mujamil. Implementasi Aswaja dalam Perspektif NU di Tengah Kehidupan Masyarakat. Kontemplasi,Volume 02 Nomor 01, Agustus 2014.

Ramli, Idrus. 2009. Madzhab As'ari Benarkah Ahlus Sunnah Wal Jamaah? Jawaban Terhadap Aliran Salafi. Surabaya: Khalista.

Santoso, Nur sayyid. Sejarah teologi islam dan akar pemikiran ahlus sunnah wal jamaah (Yoyakarta: Pustaka Pelajar, 2014).

Siradj, Said Aqil. 1997. Ahlus Sunnah Wal Jamaah dalam Lintas Sejarah. Yogyakarta: LKPSM

2008. Ahlussunnah Wal Jama'ah; Sebuah Kritik Historis. Jakarta: Pustaka Cendikia Muda. Ciganjur, 1999).

. Islam Kebangsaan Fiqh Demokratik Kaum Santri, (Jakarta: Pustaka

Sukardi, Mohammad Dawam. NU Sejak Lahir (Dari Pesantren Untuk Bangsa; Kado Buat Kyai Said), (Jakarta: SAS Center, 2010).

Tim Perumus Konsep Sosialisasi Khittah Nahdlatul Ulama PWNU Jawa Timur, Wawasan Dasar Nahdlatul Ulama, (Surabaya: Tim Perumus Konsep Sosialisasi Khittah Nahdlatul Ulama PWNU Jawa Timur, 1994). 